\title{
Dams and Dynasty, and the Colonial Transformation of Balinese Irrigation Management
}

\author{
Henk Schulte Nordholt
}

Published online: 30 April 2010

(C) The Author(s) 2010. This article is published with open access at Springerlink.com

\begin{abstract}
This article takes issue with Stephen Lansing's bottom-up model of Balinese irrigation management. Based on archival research and extensive fieldwork in the former south Balinese kingdom of Mengwi, it is argued that in precolonial days large scale irrigation depended largely on dynastic involvement. During the colonial period (19061942) the Dutch took over the role of regional irrigation management while they strengthened the autonomy of local irrigation associations.
\end{abstract}

Keywords Irrigation systems $\cdot$ Bali $\cdot$ Dynastic involvement $\cdot$ Colonial reorganization

\section{Introduction}

Colonial and post-colonial anthropological literature has paid inadequate attention to the involvement of the aristocracy in large scale irrigation in pre-colonial Bali. It has one-sidedly emphasized the cooperative-and even autonomous - nature of local irrigation networks (Grader 1960; Geertz 1980). Stephen Lansing has modified this conceptualization (1987, 2006, 2007). He also emphasizes the autonomous and bottom-up nature of local irrigation management, but adds an important qualification by arguing that regional irrigation management centered upon extended temple networks which culminated in the Batur temple complex in central Bali. In doing so, he seems to downplay, or even ignore, the role played by regional dynasties and noble lords in the pre-colonial period, while he also seems to underestimate the structural changes which

H. Schulte Nordholt $(\bowtie)$

Royal Institute of Southeast Asian and Caribbean Studies (KITLV),

Leiden, Netherlands

e-mail: SchulteNordholt@kitlv.nl took place at the beginning of the colonial period during the first decades of the twentieth century. Although he is aware that I wrote about irrigation in Bali during the pre-colonial era and the colonial period, for reasons which are not entirely clear to me, he only refers to this in a very restricted manner. ${ }^{1}$ It is true that my work is focused on another area in Bali-i.e., the southern rice plains of Mengwi and Badungwhere conditions were perhaps different from the findings of his research-i.e., in uphill Bangli and Gianyar (central Bali) — but my conclusions contradict both Lansing's model and the implicit claim in his work that it is applicable for the whole of Bali. In the following pages I will therefore summarize my findings because they offer an alternative picture of irrigation management in pre-colonial Bali.

\section{Dynasty and Irrigation in Pre-colonial South Bali}

Control of manpower was one of the main objectives of the pre-colonial contest states in Southeast Asia and the south

\footnotetext{
${ }^{1}$ See Lansing 2007: 34, where he briefly refers to my description of the role played by a regional dynasty in irrigation. He then concludes that 'only fragments of the irrigation system came under the control of even the most powerful princes,' suggesting that the nobility had no grip on the irrigation system, which is precisely not what I am arguing. Elsewhere Lansing also refers briefly to my book. He quotes me as follows: "The 'power' that upheld the theatre state remains an enigma," observed the Dutch historian Schulte Nordholt; "from where does it emanate, how is it organized, who controls it?" [Schulte Nordholt 1996: 7]' (Lansing 2006: 21). Lansing suggests that these are questions regarding the pre-colonial state in Bali which I am apparently unable to resolve. In reality, however, this sentence is part of my criticism of Clifford Geertz's famous study Negara (1980). In the remainder of my book I do suggest a set of answers, to which Lansing pays no further attention.

2 This section is primarily based on Schulte Nordholt 1996: 55-62. For detailed references to source material see Schulte Nordholt 1996.
} 
Balinese kingdom of Mengwi ( $\pm 1710-1891$ AD) was no exception in this respect. Parallel to the numerous vertical relations between lords and followers unstable connections developed between a number of large dams and the irrigated rice fields of the ordinary people. There was a correspondence between the expanding control of the dynasty over manpower and an increased grip on the irrigation systems in the region. Contrary to Lansing's model there is ample evidence that the Mengwi dynasty was closely involved in the construction, upkeep, and themostly ritual-regulation of the irrigations systems. The irrigation order can only be understood in connection with the royal hierarchy.

Three rivers, the Sungi, Penet and Ayung, descend the sloping Mengwi region which fans out from the mountains to the sea. Because the rivers cut deep gorges it was no easy to lead the water to the rice fields. Sometimes the water level of the river was dozens of feet below the rice fields, so that in order to irrigate them a dam had to be constructed many miles upstream. The water that was collected at those dams had to be diverted via lengthy conduits and tunnels before it reached the downstream rice fields.

The construction of these central dams required the mobilization of a large amount of manpower which was controlled and coordinated by either the dynasty or other local princes. In many oral histories, which I collected during my fieldwork in the early 1980s throughout the Mengwi region, mention is made that the king or a local lord ordered the clearing of land and organized the construction of upstream dams. Especially the Mengwi dynasty was involved in the establishment of large irrigation systems. The rise of the dynasty went hand in hand with the expansion of irrigated rice fields in the region.

Dynastic involvement was required because most villages had a limited range of action and cooperation between villages was often lacking. Dynastic involvement was therefore necessary in order to protect and maintain the vulnerable irrigation systems. Upkeep demanded manpower and so did reconstruction work since the large earthen dams quickly eroded in the fast-flowing rivers and were often wiped out suddenly at the start of the rainy season by a flash flood. As an example of the mechanisms by which this happened, one of the large dams in the river Ayung, dam Oongan which was some $55 \mathrm{ft}$ in height, tended to undermine itself because overflow water was diverted at the downstream side of the dam. Moreover, major conduits and tunnels required regular inspection, while the entire system had to be guarded against sabotage and external attacks. It is true that small-scale cooperation at the local level was an important feature of irrigation in Bali and this is certainly true for the twentieth century. However, without water such cooperation could not be materialized. None but regional dynasties and local lords were able to guarantee the continuity of this fragile system. ${ }^{3}$

The geographical location of the dynastic centre of Mengwi and a number of its satellites should be understood within the broader context of south Balinese irrigation. It is said that the first king of Mengwi together with a local lord who resided north of the dynastic centre built a dam in the river Sungi and proceeded to expand rice fields in his domain. As a result the dynastic centre was located in a wide fertile plain some $200 \mathrm{~m}$ above sea level where surplus for the dynasty was produced. While the newly constructed dam was guarded by the northern lord, an important side effect was that it also allowed the dynastic centre to influence downstream irrigation. In case of emergency the king was able to cut off the water supply to the domains of southern lords. This happened in the nineteenth century during prolonged conflicts between the royal centres of Mengwi and Badung, and Bangli and Gianyar.

Because the political system in Bali was fragmented there was no monopoly of power at the centre. Consequently the king was not able to control all irrigations systems in his realm. There was, in other words, no such thing as 'Oriental despotism.' Satellites of the dynasty and other lords were in control of their own irrigations systems. The lord of Sibang, for instance, had his own dam twenty miles upstream in the river Ayung which was located in the domain of another lord. The lord of Sibang had moved a group of trusted followers with their families to the north in order to maintain and protect the dam.

The lord of Sibang not only looked after his own dam, but he was also responsible for the upkeep of another big dam in the Ayung River. This was the Gumasih dam, located north of the village of Mambal. Little is known about the construction of this dam but in the course of the eighteenth century it became the biggest irrigation project in south Bali providing water for thousands of hectares of rice fields in the southern part of the Mengwi kingdom. ${ }^{4}$ The entire system was spread over the domains of several lords. Much of the upkeep of this complex system, which included a long tunnel, was delegated to lesser lords and lower units, but, the dynastic centre was ultimately responsible for the overall supervision. This supervision was vital because the system went beyond the restricted interests of its constituent parts. In this context neither bottom up coordination based on autonomous local irrigation units was able to manage this huge system, nor

\footnotetext{
${ }^{3}$ See also Happé 1915; Korn 1927; Van Naerssen 1918; Sörensen 1921.

${ }^{4}$ According to oral tradition the dam was first constructed by the lord of Mambal who was later defeated by the Mengwi dynasty. In the early 1980s the dam Mambal irrigated over 6,000 hectares of rice fields.
} 
is there any indication that it was solely managed by temples without any dynastic involvement. On the contrary, without the Mengwi dynasty the irrigation system of the Gumasih dam was simply unthinkable.

Lansing (2007: 34) seems to downplay the importance of dynastic involvement in south Bali but offers no evidence that contradicts my findings. Irrigation management was decentralized as much as possible but depended ultimately on dynastic coordination. The king and local lords had a group of functionaries (or sedahan) at their disposal who were responsible for timely repair of the dams and conduits, water allocation to irrigation units, and the collection of taxes. They also supervised the rice fields which directly belonged to their lord. Most of the tax was levied from rice fields which were distributed among followers who were given access to rice fields in exchange for labor and loyalty. This system was very common in the Mengwi kingdom. On this point, Clifford Geertz (1980: 67) presented a contrasting view regarding pre-colonial Bali that there was no 'systematic congruence [...] between the structure of political authority, the structure of land tenure, and the distribution of land tenancy.' However, all the data I was able to collect indicate the opposite. In pre-colonial Mengwi there was a strong coherence between political power, the distribution of land, and between the owner and the worker of the land, which is illustrated by the following example from the area of Sibang:

When the dam at Sibang was built, many rice fields around Sibang were opened up. The lord of Sibang reserved the largest slice of these for his own household. Most of the remaining fields were divided among his relatives. Each of them received a larger or smaller (side) canal, and they could allocate the land on either side of it to their personal followers. Trusted favorites received a larger piece of land, while ordinary followers were given about two acres.

The lord of Sibang selected the best field for his own use and his slaves grew the crop for his household. The other rice fields were called pecatu and were distributed among his personal followers. They were obliged to perform services for their lord, but were allowed to retain the complete harvest. Only a small portion of it had to be paid to the lord as tax. A follower whose loyalty and service towards the lord were found wanting would lose access to his land and was to be ousted from the circle of followers. ${ }^{5}$

\footnotetext{
${ }^{5}$ Schulte Nordholt 1996: 60. Based on an interview with Gusti Agung Putu Gedong from puri Gedong in Sibang in 1983. Elsewhere in the Mengwi region both members of the nobility as well as commoners told me similar stories. In the Mengwi region at least $50 \%$ of the rice fields were pecatu lands during the pre-colonial period, involving a lord-follower relationship (Schulte Nordholt 1996: 129).
}

In the course of the eighteenth century irrigation expanded rapidly under the encouragement of the Mengwi dynasty. But this did not mean that the king centrally controlled the whole. His control over manpower in his kingdom was limited to his own domain and so was his direct control over irrigation matters. Local lords, like the one in Sibang, managed their own decentralized systems and were in control of their own followers. As a result the fragmented control of manpower paralleled the distribution of irrigation water. In fact the top of the irrigation systems was as vulnerable as the apex of the dynastic hierarchy. A weak king or a weak dam could both cause the total system to collapse. Conversely, the irrigation order and the dynastic hierarchy could only be maintained if the royal centre was strong (see Fig. 1).

The correlation between these two hierarchies was expressed in a telling way. Until recently it was custom that in the villages of Kapal and Sibang, prior to starting to work on the rice fields, a procession would carry a sacred dynastic dagger (or keris) to the central dam. There the blade was pushed into the dam accompanied by various rituals, a result of which the powers that resided in the dagger would be infused into the dam. There is indirect evidence that similar rituals used to be held in connection with the dam north of the dynastic centre of Mengwi. This suggests that the relation between a strong ruler and a sturdy dam was crucial, because dynastic hierarchy and a smooth irrigation order supported and reinforced each other. The relationship between dynasty and irrigation management also confirms the important role kingship played in guaranteeing the continuity of fertility in the realm, which found its expression in the parallel circulation of water and the human soul between mountains, downstream valleys and the sea. ${ }^{6}$

How vulnerable both the dynastic and the irrigation orders were is nicely illustrated by a Balinese historical song, the Kidung Nderet, in which a major crisis of the Mengwi dynasty during the early $1820 \mathrm{~s}$ is told an analyzed. ${ }^{7}$ Due to poor leadership in the centre of the dynasty both the hierarchy of lords and followers and the irrigation order fell apart. An important part of the story concerns the mismanagement of the dam Gumasih near Mambal. During the reign of king Cokorda Munggu (174?1780) the responsibility for the dam, the tunnel and conduits, and part of the rice fields that received water from the dam was given to one of his sons. This man was also entitled to levy tax with which the upkeep of the dam and tunnel was paid. Under the new king, however, the

\footnotetext{
${ }^{6}$ Schulte Nordholt 1996: 143-158. The vital relationship between kingship and fertility is largely absent in Geertz' Negara (1980), nor is it discussed at any length by Lansing.

${ }^{7}$ Schulte Nordholt 1993; 1996: 100-108; Kidung Nderet (1870).
} 
Fig. 1 Mengwi in the eighteenth century (from Schulte Nordholt 1996: 54)

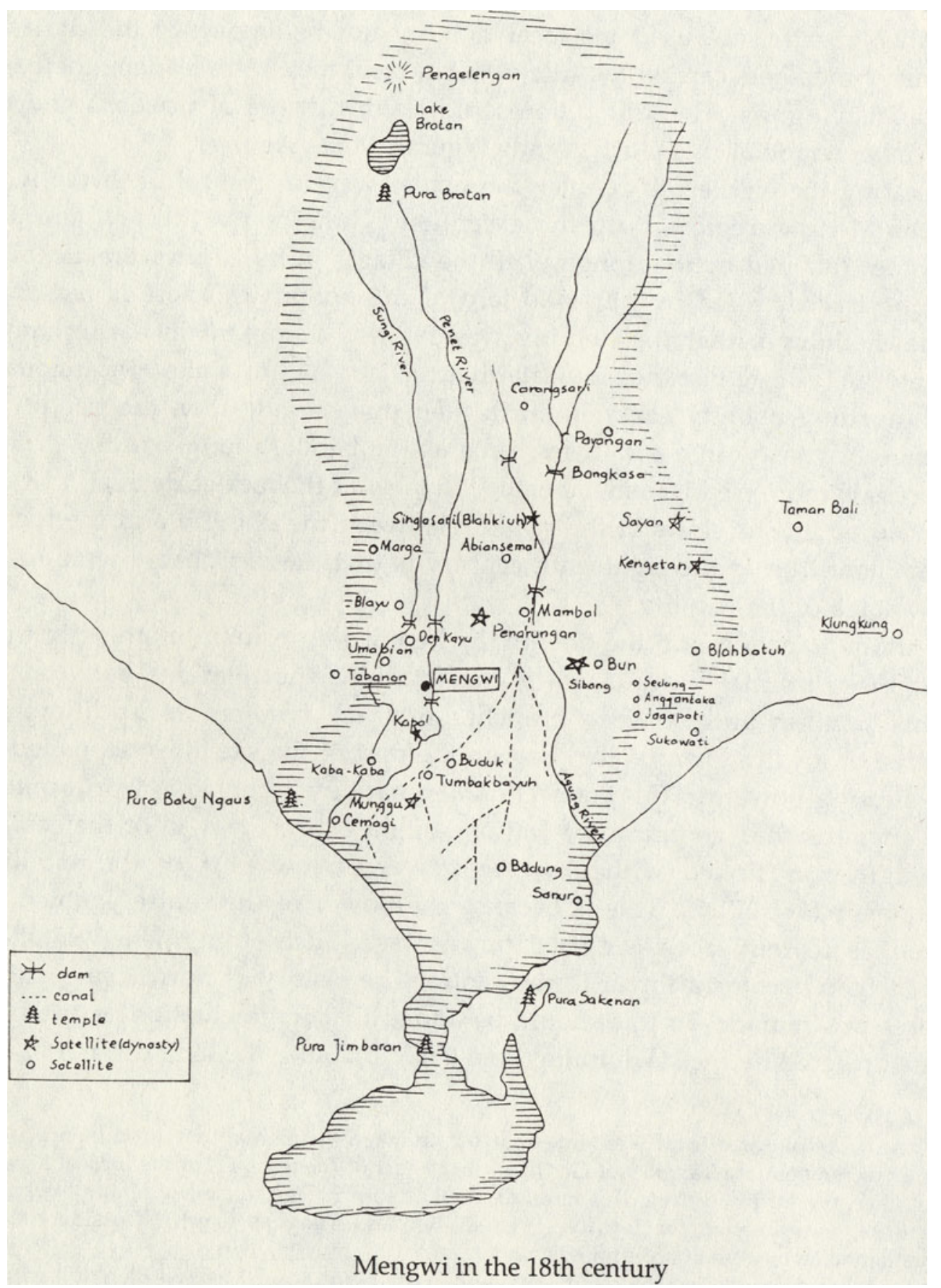

dynastic centre withdrew this privilege and resumed direct control over the irrigation system of dam Gumasih while it also centralized the taxation. But, when the dam and the tunnel needed repair, the dynastic centre did not act appropriately, as a result of which large parts of the southern rice fields did not receive any water, whereas peasants still had to pay tax. Unrest evolved eventually into protest and warfare with neighboring kingdoms, which led to a humiliating defeat. The interesting point here is that this Balinese text written in the nineteenth century also emphasizes the close connection between dynasty and irrigation. ${ }^{8}$

Around the middle of the nineteenth century the Mengwi dynasty managed to recover. Part of the recovery was the extension of rice fields in the north-

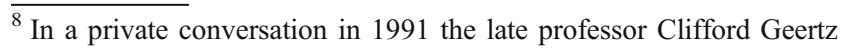
admitted reluctantly that he would have given a different picture of the nineteenth century Balinese Negara if he had known the Kidung Nderet.
} 
eastern region of the Mengwi kingdom which involved the building of dams, tunnels and temples. ${ }^{9}$ This was to a large extent a top-down operation coordinated by the leading lineage of the dynastic centre. Most likely, the actual organization of the various irrigation systems in pre-colonial Bali differed widely per locality depending on the political and ecological context. In most instances, however, lord-follower relationships informed the lines along which these systems were organized. As far as can be determined, extension of irrigated fields did not automatically result in the establishment of (semi) autonomous local irrigation units, or subak, which operated independently from villages. Oral traditions concerning this period suggest a different picture. Without exception, informants emphasized the leading role of the nobility in the project while they did not mention subak as separate organizations. Instead, they mentioned the village as the provider of labor. The term subak did exist though, but referred to a person rather than to an autonomous irrigation association. This official was the lowest link in the regional irrigation hierarchy who was also responsible for the collection of a royal tax on the use of irrigation water, the suwinih. The dynastic centre used this tax to finance large rituals in the newly built irrigation temples. These temples fostered in the first place the fertility of the land and averted plagues. The temples and rituals were supervised by irrigation officials while the dynastic involvement was restricted to the granting of permission to stage certain rituals. However, as soon as ritual and maintenance were neglected and disorder could erupt, it was the duty of the power holders to restore order and hierarchy. It is for this reason that Pura Arantaja, the main irrigation temple of the northeastern region of Mengwi, was commonly called 'pura kerajaan', or royal temple. Accordingly, this temple represented not only the link between gods, fertility, and men, but was also a reminder of royal authority in the region.

So far, I have found no evidence that supports Lansing's bottom up model of irrigation management exclusively handled by temple systems. Instead, we see a complex but integrated system in which dynasties, temples, and peasants participated and hierarchical relationships and horizontal collaboration were combined. In this system upstream irrigation was primarily coordinated and protected by the dynasty, while downstream irrigation was to a large extent a local affair. Labor was mobilized both for local purposes as well as for large scale upstream projects on dams and conduits. In terms of daily routine the system was as much as possible decentralized but the system as a whole depended in the end on dynastic coordination. Dynasties,

\footnotetext{
${ }^{9}$ Schulte Nordholt 1996: 128-131.
}

and not temples, were the key institutions that guaranteed the continuity of the system.

\section{Colonial Transformations}

Soon after the Dutch had conquered south Bali at the beginning of the twentieth century, colonial administrators started to reorganize local society according to Orientalist models of a supposed authentic Bali in which the village played a central role. Since the 'enlightened' Dutch had replaced the 'despotism' of the kings, they aimed, according to this view, to 'repair' the 'damage' inflicted upon Bali by 'arbitrary royal rule. ${ }^{, 10}$ Apart from the reorganization of village administration, which also served to mobilize a reservoir of labor, irrigation became another object of colonial interference, which ultimately aimed to levy an increasing amount of tax. ${ }^{11}$

Based on research conducted by the colonial administrator F.A. Liefrinck in north Bali the Dutch started to 'restore' south Balinese society to its 'original' state. ${ }^{12}$. His description of the northern Balinese irrigation association (subak) was taken as the normative standard for the reorganization of irrigation management in south Bali. There were, however, significant ecological differences between north and south Bali. The north featured smallscale irrigation systems without direct aristocratic interference, whereas the south had large scale systems which depended on big dams and dynastic involvement. ${ }^{13}$ Contrary to north Bali, the organization of irrigation in the south varied by locality while boundaries between village and subak were often fluid. Liefrinck had presented a uniform model in which no consideration was given to local variation or direct aristocratic involvement. As he saw it, dynastic interference was essentially unrelated to the subak, but it had penetrated into the local networks in order to appropriate taxes. This point of view reflected a very common Orientalist view of that time which favored the autonomy of local institutions which had to be protected under benign colonial rule. It seems that Lansing's ideas were at least partially influenced by this colonial perception.

Lansing argues that the Dutch deliberately sought to restore the centralized irrigation hierarchy of the former kingdoms and that they even employed archaeologists to legitimize this project (Lansing 2007: 35-36). I wonder on

\footnotetext{
${ }^{10}$ See for an elaborate analysis of the 'making of traditional Bali', Schulte Nordholt 1999.

${ }^{11}$ Schulte Nordholt 1996: 246-255; 284-286.

${ }^{12}$ Liefrinck $1886-7$.

${ }^{13}$ However, also in north Bali kings issued local irrigation regulations. See Liefrinck 1921: 310-370, for a collection of these regulations from the nineteenth century.
} 
what evidence this statement is based. Actually, the Dutch did the opposite, at least on paper.

Using Liefrinck's model, the colonial administrators in the south observed that little was left of the supposed 'original' egalitarian subak. In 1907 they embarked immediately upon an ambitious restoration program. In the same year it was reported that in the Mengwi area the subak had been 'restored' in conformity with the north Balinese model. ${ }^{14}$ What in fact happened, however, was that this so-called restoration fitted the needs of the colonial state. A memorandum on the former kingdom of Klunkung by the Dutch administrator of Bali, Resident G. F. de Bruyn Kops in 1908 illustrates this nicely:

The irrigation system, too, ought to be overhauled drastically. In the days of the kings [...] all the nobles and prominent people had their own tax collector who made sure that his own land was watered aplenty. Urgently needed is a separation between irrigation workers and administrative personnel; a division of irrigation areas, headed by a supervisor must be designed; the subak have to be assigned in groups to avoid too large a number of subak heads which would impede administrative control. ${ }^{15}$

Within a few years the Dutch succeeded in replacing the plurality of relationships from the pre-colonial period with an overarching colonial bureaucracy. For ordinary Balinese peasants the colonial reorganization marked the beginning of much confusion. Apart from administrative amalgamations, they were confronted with new officials and new or redefined terms and titles. In each former kingdom, which had become an administrative district, a Balinese official (sedahan agung) was appointed who supervised a number of lower officials (sedahan) who on their turn both supervised the distribution of irrigation water and the levying of new colonial taxes. While the term subak was known as a local irrigation leader in the Mengwi area, it now became the name of the local irrigation association all over Bali. The Dutch introduced a new term for the subak leader, i.e., pekaseh, which was taken from the neighboring kingdom of Gianyar. These terminological shifts were not insurmountable, but great confusion ensued when the Dutch started to reorganize the actual irrigation networks. Bureaucratic and administrative criteria prevailed to the extent that irrigation networks had to coincide with administrative borders. This implied that quite a number of irrigation districts no longer formed coherent ecological systems as a result of which the proper flow of water was seriously hampered. Moreover, small irrigation

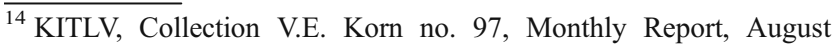
1907, by Assistant Resident of South Bali, H.J.E.F. Schwartz.

${ }^{15}$ Memorandum Resident G.F. de Bruyn Kops September 8, 1908, Colonial Archive V 15-9-1909 no. 30, National Archives The Hague.
}

units were amalgamated to form fewer and bigger irrigation associations which were organized according to a uniform model. In this way the basis was laid for a new colonial system of taxation. Within ten years the twelve irrigation districts that had been formed in the former kingdoms of Badung and Mengwi in 1907 were reduced to six. These amalgamations led to irrigation areas of such a size that proper coordination was no longer possible. Whereas in former days a large number of sedahan had coordinated these tasks, these fell now to a single official who was often not familiar with local conditions. The distance between peasants and officials at the regional level increased due to a process of ongoing bureaucratization. Since the Dutch preferred candidates with bureaucratic skills in order to collect taxes, there was a loss of expertise in irrigation matters.

Amalgamation not only affected regional irrigation management, but local arrangements as well. Countless small irrigation associations were amalgamated into new and bigger subak. To some extent however, the old cooperative arrangements continued to function as sub-units, or munduk or tempek, within larger subak. The difference was, however, that these sub-units depended for water supply on the larger subak and its head.

Perhaps the most important structural change took place from 1914 onwards when the old vulnerable earthen dams and conduits were gradually replaced by new strong concrete constructions. Since the Dutch had conquered the south Balinese kingdoms, dynastic control of dams and main conduits was discontinued. As a result some large dams collapsed between 1909 and 1914 and hundreds of hectares of rice fields fell dry. From now on the Dutch were responsible for irrigation at the regional level. Between 1914 and 1931 four concrete dams were build in the Ayung River which together irrigated 12,763 hectares of rice fields. ${ }^{16}$ Lansing does not seem to be fully aware of the fundamental changes this brought to irrigation management.

In contrast to the pre-colonial period these new permanent constructions guaranteed a steady supply of water flowing to the rice fields. The responsibility for the building and maintenance of the new concrete structures fell under a separate institution of the colonial state, the Public Utilities Service, which replaced the mobilization of labor under dynastic supervision. Consequently, the manifold connections between local irrigation associations and central water supply, which involved in the pre-colonial period the regular mobilization of hundreds of people by dynastic officials to repair the central dam and the main conduits,

\footnotetext{
$\overline{16}$ These were dam Oongan (built between 1914-1929, irrigating 3,284 hectares), dam Praupan (1920-1924, 365 ha.), dam Mambal (1926-1927, 6,000 ha.), and dam Kadewatan (1927-1931, 3,150 ha.).
} 
fell into disuse. Moreover, colonial pacification made an end to regional warfare which had often threatened the continuity of the irrigation process.

It was only because of these new conditions that for the peasants in south Bali irrigation became primarily a local affair. Ironically, it was this colonial intervention which was instrumental in achieving the colonial image of the 'original' Balinese subak as a strictly local and 'autonomous' institution. As the Dutch did not interfere in the ritual activities that accompanied the flow of the seasons, this was left to the population as well.

Consequently irrigation management at the local level and ritual affairs remained outside the domain of the colonial state.

According to Lansing $(2006,2007)$ irrigation management in Bali has been a bottom-up process which was and still is supported by networks of autonomous associations while cooperation and coordination is structured by temple networks. Since I have not conducted research in central Bali, I will refrain from criticizing Lansing's findings in that area. ${ }^{17}$ What I want to emphasize is that south Bali offered a different picture. Here, large scale irrigation in the precolonial period was unthinkable without dynastic involvement. To say this, of course, is not to deny the important role that peasant associations play in day-to-day irrigation management at the local level. ${ }^{18}$ Structural changes which occurred during the colonial period created more local autonomy in irrigation management while temples still played a crucial role. Hence, it could very well be the case that what Lansing tends to perceive as authentic self organizing processes, were actually the result of a colonial transformation which took place at the beginning of the twentieth century.

Open Access This article is distributed under the terms of the Creative Commons Attribution Noncommercial License which permits any noncommercial use, distribution, and reproduction in any medium, provided the original author(s) and source are credited.

\section{References}

Geertz, C. (1980). Negara. The Theatre State in Nineteenth Century Bali. Princeton University Press, Princeton.

Grader, C. J. (1960). The irrigation system in the region of Jembrana. In Swellengrebel, J. L. (ed.), Bali. Studies in Life, Thought, and Ritual. Van Hoeve, The Hague, pp. 267-288.

Happé, P. L. E. (1915). Eenige bijzonderheden omtrent de inlandsche rijstcultuur in Zuid-Bali. Indisch Bouwkundig Tijdschrift 18-21: 401-407.

Hauser-Schäublin, B. (2003). The Precolonial Balinese State Reconsidered. A Critical Evaluation of Theory Construction on the Relationship Between Irrigation, the State and Ritual. Current Anthropology 44: 153-181.

Kidung Nderet. (1870). Oriental Manuscripts Collection, Leiden University 13.060 .

Korn, V. E. (1927). Balische bevloeiingstunnels. Koloniale Studiën 11: $351-381$.

Lansing, J. S. (1987). Balinese "Water Temples" and the Management of Irrigation. American Anthropologist 89: 326-341.

Lansing, J. S. (2006). Perfect Order. Princeton University Press, Recognizing complexity in Bali. Princeton/Oxford.

Lansing, J. S. (2007). Priests and Programmers. Technologies of Power in the Engineered Landscape of Bali. Princeton University Press, Pricenton/Oxford [originally published in 1991].

Liefrinck, F. A. (1886-7). De rijstcultuur op Bali. Indische Gids 8-2: 1033-1059, 1213-1237, 1557-1568; 9-1: 17-30, 182-189, 364 $385,515-552$.

Liefrinck, F. A. (1921). Nog eenige verordeningen en overeenkomsten van Balische vorsten. Martinus Nijhoff, 'sGravenhage.

Pedersen, L. (2006). Ritual and World Change in a Balinese Princedom. Carolina Academic Press, Durham.

Schulte Nordholt, H. (1993). Leadership and the Limits of Political Control. A Balinese 'Response' to Clifford Geertz. Social Anthropology 1: 291-307.

Schulte Nordholt, H. (1996). The Spell of Power. A History of Balinese Politics 1650-1940. KITLV, Leiden.

Schulte Nordholt, H. (1999). The making of traditional Bali: Colonial ethnography and bureaucratic reproduction. In Pels, P., and Salemink, O. (eds.), Colonial Subjects. Essays on the Practical History of Anthropology. University of Michigan Press, Ann Arbor, pp. 241-281.

Sörensen, O. W. (1921). Irrigatie in Zuid-Bali. De Waterstaatsingenieur 4: 116-121.

van Naerssen, E. J. (1918). Irrigatie en waterverdeling volgens de opvatting der Baliërs. Adatrechtbundel 15: 27-39.

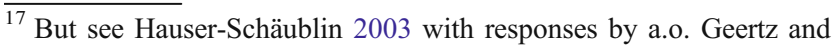
Lansing.

${ }^{18}$ See Pedersen 2006: 228-229, for a similar view.
} 